\title{
Tree Growth, Litter Fall and Leaf Litter Decomposition of Eucalyptus tereticornis Base Agri-silviculture System
}

\author{
Tarun Kumar ${ }^{1}$, Bimlendra Kumari ${ }^{1}$, Sandeep Arya ${ }^{1}$ and Prashant Kaushik ${ }^{2}$ \\ ${ }^{1}$ Department of Forestry, CCS Haryana Agricultural University, \\ Hisar-125 004, Haryana (India) \\ ${ }^{2}$ Instituto de Conservación y Mejora de la Agrodiversidad Valenciana, \\ Universitat Politècnica de València, 46022 Valencia, Spain \\ *Corresponding author
}

\section{A B S T R A C T}

\section{Keywords}

Tree growth, Leaf litter, Base agrisilviculture system, Eucalyptus tereticornis

Article Info

Accepted:

20 March 2019

Available Online:

10 April 2019
Tree growth, litter fall and leaf litter decomposition, nutrient return thought leaf litter and litter decomposition were 7 year old Eucalyptus tereticornis plantation. The Tree growth under agri-silvicultural system at the beginning of experiment the observations recorded with respect to certain growth parameters of Eucalyptus tereticornis have been shown Table 1 in 2014-2015. The maximum tree height $(21.80 \mathrm{~m})$ found in tree no 5; Dbh $(22.63$ $\mathrm{cm})$ and canopy width $(5.82 \mathrm{~m})$ were recorded in the same tree number 3 . Whereas the maximum canopy length $(6.32 \mathrm{~m})$ was found in the tree number 3 . In the next year 20152016 the observations recorded with respect to certain growth parameters at the end of experiment of Eucalyptus tereticornis have been shown in Table 2 and the maximum tree height $(22.78 \mathrm{~m})$ found in tree no 5 ; Dbh $(24.48 \mathrm{~cm})$ and canopy width $(6.17 \mathrm{~m})$ were recorded in the same tree number 3 . Whereas the maximum canopy length $(7.61 \mathrm{~m})$ was found in the tree number 3 . The maximum litter from litter trap was recorded in $(59.94 \mathrm{~g})$ month of November during 2014-2015 and the minimum litter from litter traps was found in (6078 g) month of November during the year 2015-2016.

\section{Introduction}

Eucalyptus tereticornisis renowned globally for its fast growth, high levels of drought tolerance and adaptability to diverse climatic conditions and soils, which makes it popular among eucalypt tree growers Bindumadhava et al., (2011). Colonel propagation is an extensively used strategy to gain economic potential of eucalypt species/hybrids by multiplying desirable types. With moderate degree of sophistication in most forest nurseries, it is performed to strategically improve the productivity Zobel et al., (1995).To protect natural resources and the environment for the sustainable development, plantation has become the major source of timber supply for timber industry such as solid wood, plywood pulping and paper.

A good plantation species should produce not only high timber yield, but also the desired properties of wood for highly valued end products. Accelerating tree growth rate or 
shortening the rotation could potentially affect wood qualityAlterac et al., (2005).

The total area of eucalypts planted in India is estimated to exceed 2,500,000 ha Midgley et al., (2002). Several pulp and paper mills, forest departments and forest development corporations have substantial areas of plantations either directly under their control or in farmer's land from which wood is purchased. Most eucalypt plantations across India are of 'Mysore Gum', a land race considered to be a mixture of pure Eucalyptus tereticornis Smith and genetic segregates of inter specific hybrids, displaying high variability (Kaikini, 1961). The growth of Mysore Gum is quite slow; with mean annual increment of plantations averaging around 7 $\mathrm{m}^{3} \mathrm{ha}^{-1}$ (Chandra, 1992); and a number of trials have demonstrated superior performance of certain new eucalypt introductions or selected eucalypt clones. Eucalypts are the major raw material of the pulp and paper industries in India, so it is imperative that planting stock of high genetic quality be used to increase the yield from plantations mainly for Eucalypts. Due to the limited resources in arid and semi-arid regions, benefits from short rotation forests largely depend on the judicious management of soil and water resources. Improved selection of appropriate tree species and growth of trees at optimum densities are important management considerations to increase overall system productivity.

Tree stand density is a very important tool of silvicultural treatment and offer a means to affect the growing conditions of trees and thus, also the stem wood production. With the worldwide move towards intensive silviculture and shorter rotations, the quality of wood and end products from this changing resource has become a concern for the forest products industry.

\section{Materials and Methods}

\section{Site description}

The present study entitled "Tree growth, Litter fall and leaf litter decomposition of Eucalyptus tereticornisbase agri-silviculture system" was carried out at Research Farm of the Department of Forestry, CCS Haryana Agricultural University, Hisar during the year 2014-15 and 2015-16.

The experimental site is situated at $29^{\circ} 09^{\prime} \mathrm{N}$ latitude and $75^{\circ}$ 43' $\mathrm{E}$ longitudes at an elevation of $215 \mathrm{~m}$ above mean sea level situated in semi-arid region of the Northwest India. The climate is subtropical-monsoonic with an average annual rainfall of 350-400 $\mathrm{mm}$ and $70-80 \%$ of which occurs during July to September. The summer months are very hot with maximum temperature ranging from 40 to $45^{\circ} \mathrm{C}$ in May and June, whereas, December and January are the coldest months (lowest January temperature as low as $0^{\circ} \mathrm{C}$ ).

\section{Experimental design planting}

Seven year old Eucalyptus tereticornis were planted in $6 \times 1.5 \mathrm{~m}$ under agri-silviculture system. The experiment was set up in Randomized Block Design. Under system agriculture crop was grown in Barley.

\section{Estimation of soil physic-chemical properties}

The soil sample was collected in before and after the experiment in both years under agrisilviculture system and open area. The soil was sampled using a $45 \mathrm{~mm}$ diameter hand auger. Visible roots and organic residue were removed during sampling. Soil sample are dried, sieved and stored in cotton bags, before analysis. Available nitrogen was measured Micro-Kjendal (Piper, 1950) procedure. Total available phosphorus (P) was measured (calorimetrically) and total available 
potassium (K) by flame photometer (Jackson, 1973).

\section{Litter fall determination}

Litter production was measured for 2 consecutive years continually from January 2014 till December 2016. Litter collection was made using wooden traps and 10 traps were randomly placed in under agrisilviculture system to represent an average of the total area.

Each trap was $50 \mathrm{~cm} \times 50 \mathrm{~cm}$ depth to allow accumulation of falling litter. The randomly distributed litter traps was accordance with the method suggested by New-bould1967and Chapman1976.

The traps were fixed about $80-100 \mathrm{~cm}$ above ground level by pegs at the corners. The litter fall was collected at monthly interval over the annual cycle. After collection, the litter was separated into different categories viz., leaf litter, woody litter and miscellaneous litter and oven dried at $60^{\circ} \mathrm{C}$ constant weight.

\section{Litter decomposition}

Decomposition of Eucalyptus tereticornis litter was studied using the standard litter-bag techniques (Falconer et al., 1933).

This study was carried out from June 2014 to May 2016. Freshly collection litter (only leaf) weighing $10 \mathrm{~g}$ was placed in bags $(20 \mathrm{~cm} \times 20$ $\mathrm{cm})$ made from nylon net $(2.0 \mathrm{~mm}$ mesh size) and scattered at the agri-silviculture system. In total, there were 120 bags and three bags were removed randomly at monthly intervals. The bags were carefully tapered to remove adhering soil particles. The content was oven dried at 600c and weighed rate of litter loss was determined based on remaining contents of bags.

\section{Results and Discussion}

\section{Tree growth}

The observations recorded with respect to certain growth parameters of Eucalyptus tereticornis have been shown in Table 1 . The maximum tree height $(21.80 \mathrm{~m})$ found in tree no 5; Dbh $(22.63 \mathrm{~cm})$ and canopy width $(5.82$ $\mathrm{m})$ were recorded in the same tree number 3 . Whereas the maximum canopy length $(6.32$ $m)$ was found in the tree number 3 . In the next year 2015-2016 the observations showed in Table 2 at the end of experiment of maximum tree height $(22.78 \mathrm{~m})$ found in tree no 5 ; Dbh $(24.48 \mathrm{~cm})$ and canopy width $(6.17 \mathrm{~m})$ were recorded in the same tree number 3 . Whereas the maximum canopy length $(7.61 \mathrm{~m})$ was found in the tree number 3.Results showed that the growth parameters of Eucalyptus tereticornis were significantly affected by the annual crops.

\section{Total litter fall from litter trap}

Litter fall in Eucalyptus tereticornis base agrisilviculture system the observation regarding Litterfall showed in table 3 and fig 1 and 2. It is evident from the table that the maximum litter from litter trap $(59.94 \mathrm{~g})$ was found in month of November followed by (38.75) in January and the minimum leaf litter(17.39 g) recorded in month of July during 2014-2015. In the next year 2015-2016 the maximum litter from litter trap $(60.78 \mathrm{~g})$ was found in month of November and the minimum leaf litter $(18.85 \mathrm{~g})$ recorded in month of July.

As evident from the results that the maximum leaf fall $(50.32 \mathrm{~g})$, wood fall $(22.63 \mathrm{~g})$ and miscellaneous fall $(1.70 \mathrm{~g})$ were found in month of November, September and may during and the minimum leaf fall (3.47 g), wood fall $(2.18 \mathrm{~g})$ and miscellaneous fall $(0.002 \mathrm{~g})$ were found in month of August, December and July during 2014-2015. 
In the next year 2015-2016 the observation recorded maximum leaf fall $(50.98 \mathrm{~g})$, wood fall $(23.88 \mathrm{~g})$ and miscellaneous fall $(2.10 \mathrm{~g})$ were found in month of November, September and May and the minimum leaf fall (3.78g), wood fall $(2.78 \mathrm{~g})$ and miscellaneous fall $(0.030 \mathrm{~g})$ were found in month of August, November and July (Table 4).

Table.1 Effect of litter fall and decomposition on tree growth at the beginning experiment in Eucalyptus tereticornis under agri-silviculture system during2014-2015

\begin{tabular}{|c|c|c|c|c|}
\hline \multirow[t]{2}{*}{ Tree no } & \multicolumn{4}{|c|}{ Growth at the beginning of experiment } \\
\hline & Tree height (m) & Dbh (cm) & $\begin{array}{l}\text { Canopy width } \\
\text { (m) }\end{array}$ & $\begin{array}{l}\text { Canopy length } \\
\text { (m) }\end{array}$ \\
\hline 1 & 18.70 & 22.05 & 5.47 & 5.37 \\
\hline 2 & 18.96 & 21.90 & 5.67 & 6.28 \\
\hline 3 & 19.66 & 22.63 & 5.82 & 6.34 \\
\hline 4 & 18.31 & 22.33 & 5.41 & 5.52 \\
\hline 5 & 21.80 & 22.46 & 5.57 & 5.16 \\
\hline CD at $5 \%$ & 1.68 & 1.06 & 0.64 & 0.253 \\
\hline SEm \pm & 0.52 & 0.44 & 0.19 & 0.082 \\
\hline
\end{tabular}

Table.2 Monthly estimation of litter from litter traps in 7 year old Eucalyptus tereticornis plantation under agrisilviculture system

\begin{tabular}{|l|l|l|l|}
\hline \multirow{2}{*}{$\begin{array}{l}\text { Treatment/mont } \\
\text { hs }\end{array}$} & \multicolumn{2}{|l|}{ Monthly Litter from litter trap $\left(\mathbf{g ~ m}^{-\mathbf{2}} \mathbf{m o n t h}^{\mathbf{- 1}}\right)$} & \\
\cline { 2 - 3 } & Litter fall & Litter fall & Total \\
\cline { 2 - 3 } January & $\mathbf{2 0 1 4 - 1 5}$ & $\mathbf{2 0 1 5 - 1 6}$ & \\
\hline February & 25.75 & 40.03 & 78.78 \\
\hline March & 21.56 & 26.55 & 52.41 \\
\hline April & 25.54 & 21.79 & 43.30 \\
\hline May & 24.65 & 26.46 & 52.00 \\
\hline June & 23.71 & 26.00 & 50.64 \\
\hline July & 17.39 & 26.17 & 49.88 \\
\hline August & 19.49 & 18.85 & 36.24 \\
\hline September & 33.65 & 21.40 & 40.89 \\
\hline October & 37.59 & 35.34 & 68.99 \\
\hline November & 59.94 & 38.36 & 75.95 \\
\hline December & 35.65 & 60.78 & 120.72 \\
\hline CD at 5\% & 6.24 & 36.06 & 71.71 \\
\hline SEm \pm & 0.41 & 6.05 & \\
\hline
\end{tabular}


Table.3 Effect of litter fall and decomposition on tree growth at the end of experiment inEucalyptus tereticornisunder agri-silviculture system during 2015-2016

\begin{tabular}{|c|c|c|c|c|}
\hline \multirow[b]{2}{*}{ Tree no } & \multicolumn{4}{|c|}{ Growth at the beginning of experiment } \\
\hline & Tree height (m) & Dbh (cm) & $\begin{array}{l}\text { Canopy width } \\
\text { (m) }\end{array}$ & $\begin{array}{l}\text { Canopy length } \\
\text { (m) }\end{array}$ \\
\hline 1 & 19.49 & 24.10 & 5.67 & 6.59 \\
\hline 2 & 19.29 & 23.54 & 6.04 & 7.31 \\
\hline 3 & 20.39 & 24.48 & 5.96 & 7.61 \\
\hline 4 & 19.65 & 24.42 & 5.58 & 6.84 \\
\hline 5 & 22.78 & 24.35 & 6.17 & 5.75 \\
\hline CD at $5 \%$ & 2.14 & 1.87 & 0.43 & 0.315 \\
\hline SEm \pm & 0.64 & 0.55 & 0.13 & 0.851 \\
\hline
\end{tabular}

Table.4 Monthly estimation of different categories of litter fall in 7 year old Eucalyptus tereticornis plantation under agri-silviculture system of sodic land

\begin{tabular}{|c|c|c|c|c|c|c|c|}
\hline \multirow{3}{*}{ Treatment/months } & \multicolumn{6}{|c|}{ Litter component ( $\mathrm{g} \mathrm{m}^{-2}$ month $\left.^{-1}\right)$} & \multirow{3}{*}{ Total } \\
\hline & \multicolumn{2}{|c|}{ Leaf litter } & \multicolumn{2}{|c|}{ Wood litter } & \multicolumn{2}{|c|}{$\begin{array}{l}\text { Miscellaneous } \\
\text { litter }\end{array}$} & \\
\hline & $\begin{array}{l}2014- \\
15\end{array}$ & $\begin{array}{l}2015- \\
16\end{array}$ & 2014-15 & $\begin{array}{l}2015- \\
16\end{array}$ & $\begin{array}{l}2014- \\
15\end{array}$ & 2015-16 & \\
\hline January & 35.037 & 35.680 & 3.083 & 3.533 & 0.400 & 0.480 & 78.213 \\
\hline February & 19.108 & 19.717 & 6.483 & 6.417 & 0.040 & 0.076 & 51.841 \\
\hline March & 8.867 & 8.528 & 12.000 & 12.417 & 0.408 & 0.508 & 42.728 \\
\hline April & 18.217 & 18.762 & 6.467 & 6.683 & 0.628 & 0.676 & 51.433 \\
\hline May & 14.432 & 14.925 & 8.283 & 8.633 & 1.700 & 2.100 & 50.073 \\
\hline June & 6.642 & 7.507 & 16.533 & 17.867 & 0.307 & 0.454 & 49.31 \\
\hline July & 4.840 & 4.520 & 12.317 & 13.950 & 0.002 & 0.040 & 35.669 \\
\hline August & 3.477 & 3.783 & 15.733 & 17.250 & 0.050 & 0.030 & 40.323 \\
\hline September & 10.733 & 11.087 & 22.633 & 23.883 & 0.050 & 0.030 & 68.416 \\
\hline October & 29.877 & 29.987 & 7.417 & 8.000 & 0.070 & 0.030 & 75.381 \\
\hline November & 50.322 & 50.982 & 9.350 & 9.417 & 0.040 & 0.040 & 120.151 \\
\hline December & 32.895 & 32.680 & 2.183 & 2.583 & 0.342 & 0.456 & 71.139 \\
\hline CD at $5 \%$ & 1.314 & 0.906 & 0.414 & 0.967 & 0.124 & 0.214 & \\
\hline
\end{tabular}




\begin{tabular}{|l|l|l|l|l|l|l|l|}
\hline SEm \pm & 0.462 & 0.319 & 0.146 & 0.340 & 0.044 & 0.075 & \\
\hline
\end{tabular}

Fig.1 Relationship between month and remaining weight (\%) of litter in Eucalyptus tereticornis base agri-silviculture system during 2014-2015

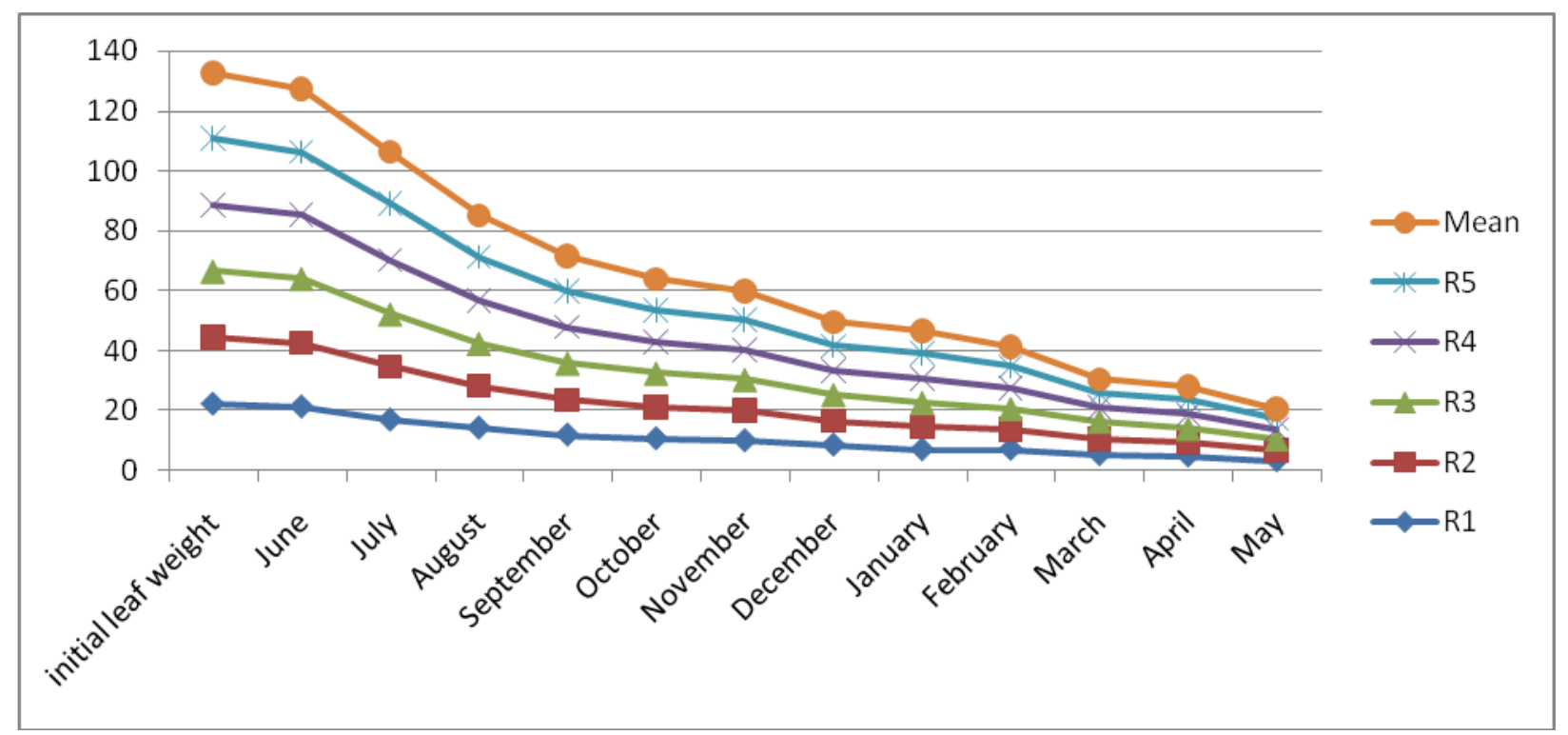

Fig.2 Relationship between month and remaining weight (\%) of litter in Eucalyptus tereticornis base agri-silviculture system during 2015-2016

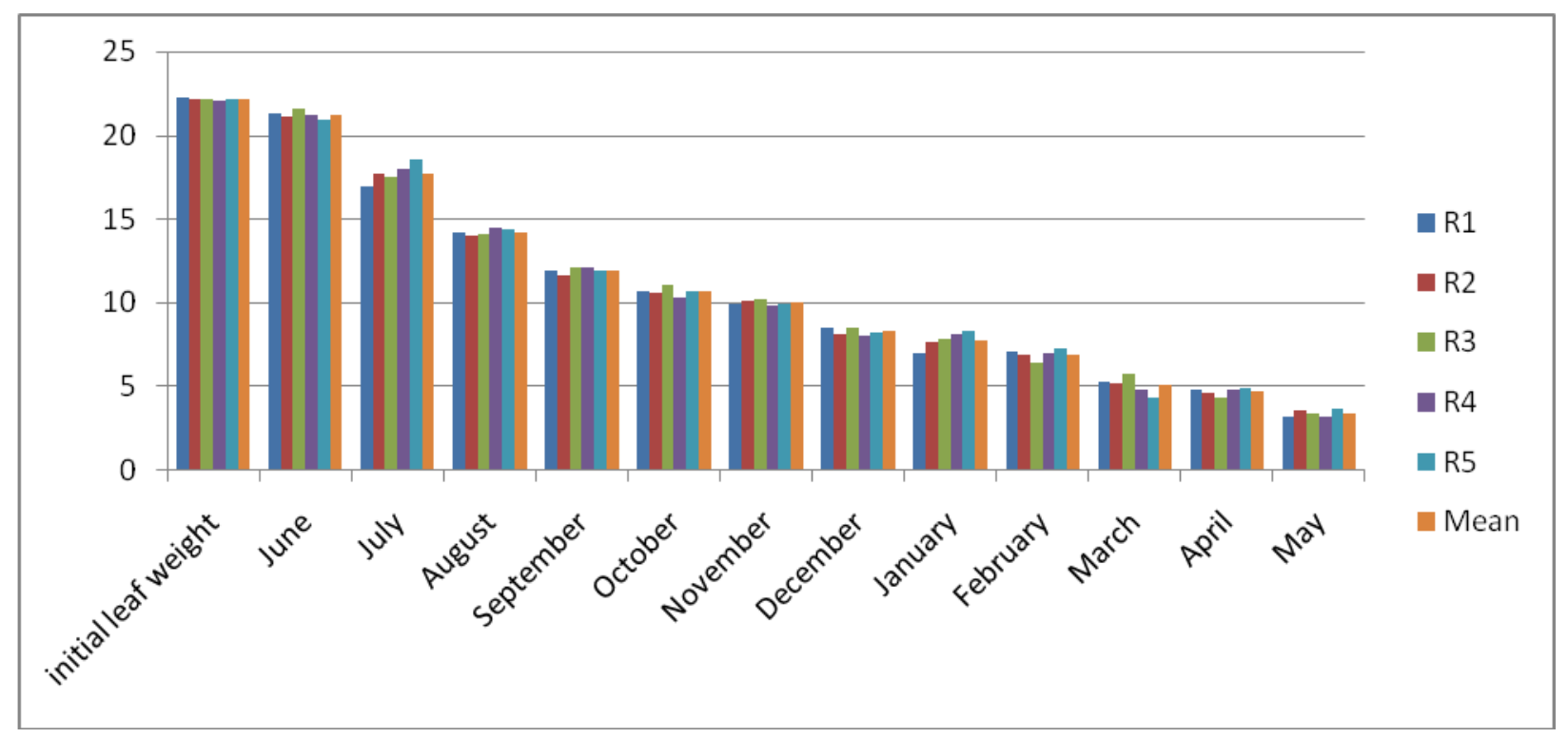

\section{Tree growth}

Results of the present study provide valuable information that supports the establishment tree growth of Eucalyptus tereticornis base agri-silviculture system. The growth of Eucalyptus tereticornis increased with light, moisture and available nutrients. Therefore, 
regular irrigation helps to make nutrient available in rahizosphere. Beneficial nutrient may be influenced by plant roots directly in tripartite association between Casuraina and Frankia and mycorrhiza Reddell 1990; Rajendran and Devaraj 2004. In our study 2014-2015, significant growth at the beginning of experiment was recorded in maximum tree $(21.80 \mathrm{~m})$, dbh $(22.63 \mathrm{~m})$ and canopy width, canopy length was found in $(5.82 \mathrm{~m}),(6.34 \mathrm{~m})$ of 7 year old plantation. The overall growth improvement may be attributed to improved genetic material available. Accumulation of biomass may be related to intensive silvicultural management such as superior genetic materials, appropriate distance, regular watering, weeding and manuring. However, growth of trees was markedly higher while adopting systematic cultivation method using suitable biofertilisers. In addition, excellent growth was observed in the height ofEucalyptus tereticornis which ranged from 9.87 to 11.90 $\mathrm{m}$ and girth at breast height which ranged from 16.8 to $23.2 \mathrm{~cm}$ after planting (Rajendranand Devaraj, 2004).

\section{Litter production}

The litter fall of Eucalyptus tereticornis studied indifferent component at monthly interval. However, the rate of leaf fall on seasonal basis was greatest in winter (November to February) followed by summer (March to June) and Rainy season (July to October). A similar Pattern was also observed for total above ground tree litter fall under agri-silviculture system (Saravanan et al., 2012). Litter production is directly related to the availability to nutrient and fast growth of species. There is more pressure on soil nutrient as more number of trees is present in under agri-silviculture system. However, some amount of nutrient is returned to the soil through leaf litter. In the present estimation the maximum litter fall $(52.45 \mathrm{~g})$ to $(68.23 \mathrm{~g})$ was found during November to February. Total litter fall545 $\mathrm{g} \mathrm{m}$ observed in the present study is lower than that of the reported value for nearby only tree plantation. Malaya and Nisanka (1997) was reported the data on cumulative litter fall for 24 months ranged between5784 g m-2 (12-13 years) tree plantation.

In addition to evergreen nature of the species, litter fall in Eucalyptus tereticornis plantation under agri-silviculture system throughout the year may be attributes to the growth pattern of the species coupled with favourable environmental factors, especially atmospheric and wind velocity. Maximum litter fall during winter (November to February) was due to heavy spike shedding. Besides, maximum litter fall during winter might also be light intensity, temperature and moisture Rana et al., 2007;Bray and Gorham 1964. This pattern of leaf fall is comparable with other plantations of this region. The leaf fall accounted for $64.3 \%$ (Eucalyptus hybrid) to $90.8 \%$ (D. sissoo) of the total annual litter fall which is within the range of $37.7-96.3 \%$ reported for different other plantations Meentemeyer et al., 1982 calculated 70\% leaf litter in the total litter fall in forests around the world. The annual woody litter fall estimated in this study ranging between 16.6 and 131.8 g m-2 year-1 is comparable with other plantations of similar age. The total litter fall for C. Equisetifoila in this study $(664.77 \mathrm{~g} \mathrm{~m}$ 2 year-1) is similar to that produced by a $C$. equisetifoila (455-824 g m-2 year-1) plantation on the sandy coast of Orissa and by a E. oblique (388-537 g m-2 year-1) plantation in New Zealand. However, the present value in this study was lower than the values reported for the coastal hills of Africa and for Eucalyptus hybrid in Uttaranchal Tarai, Casuraina spp. in Kerela, India but litter fall peak winter followed by summer higher reported by. Baker1983;Pande and Sharma 1986.Total litter production by $C$. 
equisetifolia, in the present study was lower than the plantations of the same species raised in coastal Orissa, Uttaranchal Tarai and Kurukshetra regions respectively. Overall comparison, in general, indicated that the litter production on the present sites was lower than the stands at other sites. The relatively lower values of litter production in the present study may be due to the slow growth of trees on sodic land and subsequent slow turnover of biomass.

\section{Litter decomposition}

The higher rate of litter production and its subsequent decomposition under agrisilviculture system turnover of nutrients and affected nutrient cycling. Litter quality has been considered as an important factor controlling decomposition Ribeiro et al., (2002); Tateno et al., (2007. The processes of leaf decay are largely controlled by soil microorganisms and are, therefore, influenced by temperature, moisture, $\mathrm{pH}$ and soil microorganisms (Jenkinson 1981). Maximum decomposition was recorded during 20142015 (3.52 g m-2) and 2015-2016 (3.45 g m2) in month of July during the rainy season followed by summer and winter. This isobvious from the positrate of weight loss and soil moisture and rainfall (Austin and Vitousek, 2000; Dasselar and Latinga, 2000). The high rate of decomposition (rainy season) attributable to suitable temperature and moisture was due to regular irrigation, rainfall, fungal population and soil aeration. Similar observations were observed for Eucalyptus, Dipterocarpus tuberculatus and oakconifer forest (Wedderburn and Carter 1999; Sarjubala and Yadava 2007).

In conclusion, the amount of above ground tree litter production was lower than present agrisilviculture system on sodic soil then other plantation located on normal site may be because of slower growth rate of the former.
Under system maximum litter fall in Eucalyptus tereticornis and fast decomposition. Present study clearly indicates the scope of using the leaf litters of Eucalyptus tereticornisas green. Uder adverse soil and different climatic conditions Eucalyptus tereticornis (a species of coastal origin) reflected indifference and assumed greater potential of biomass and productivity than other species Rana et al., (1998). By inclusion of Eucalyptus tereticorni $s$ in agroforestry, satisfactory improvement in wheat and paddy crop yield on sodic soil occurred within few year of intensive cultivation in the same locality Parihar and Rana (1999).

\section{References}

Alterac, J., S.Y. Zhang and A. Cloutier, 2005. Influence of stand density on ring width and wood density at different sampling heights in black spruce. Wood and Fiber Science, 37(1): 83-94.

Austin AT and Vitousek PM 2000. Precipitation, decomposition and litter decomposability of Metrosideros polymorpha in active forests on Hawaii. Journal of Ecology 88: 129-138.

Baker T. G. 1983. Dry matter, nitrogen and phosphorus content of litter fall and branch fall in Pinus radiata and Eucalyptus forests. New Zealand Journal of Forest Science 13: 205-221.

Bargali S. S; Singh S. P; and Singh R. P 1992. Structure and function of an age series of eucalypt plantations in Central Himalaya. I. Dry matter dynamics. Annals of Botany 69: 405-411.

Bernhard-Reversta, F. 1993. Dynamics of litter and organic matter at the soil-litter interface in fast-growing tree plantations on sandy ferrallitic soils (Congo). Acta Oecologia 14: 179-195.

Bindumadhava, H., J. Tamak, K. Mahavishnan, A.P. Upadhyay, M. 
Varghese and N. Sharma, 2011. Clonal propagation in Eucalyptus camaldulensis using minicutting technique, Current Science, 101(12): 1578-1585.

Bray J.R; and Gorham E 1964. Litter production in forests of the world. Advances in Ecology Research 2: 101157.

Chandra, K.M., S.S. Patnaik and K. Gurumurthi, 1992. Country report India, In: Tree Breeding and Propagation, Part II Regional Review and Country Reports, Field Document No. 2, FAO/ UNDP Project RAS/88/025, Bangkok, pp: 49-68.

Chapman, S.B. 1976. Production ecology and nutrient budgets. pp. 157-228. In: S.B. Chapman (ed.) Method in plant Ecology, Blackwell Scientific publications, Oxford.

Dasselar AVV and Latinga EA. 2000.Modeling the carbon cycle of grassland in the Netherlands under various management strategies and environmental conditions. Journal of Agricultural Science 43: 183-194.

Falconer GJ; Wright JW and Beall HW. 1933. The decomposition of certain types of fresh litter under field conditions. American Journal of Botany 20: $196-203$

Jackson ML. 1973. Soil Chemical Analysis 1981 Prentice-Hall of India (Pvt) Ltd, New Delhi

Jenkinson DS 1981.The fate of plant and animal residues in soil. Pp 505-561 in Greenland DJ and Hayes MHB (eds) The Chemistry of Soil Processes. John Wiley and Sons, Chichester.

Joshi C. S., Rao P. B; and Singh R. P. 1997. Comparative study of litter fall and nutrient return in some plantations of Central Himalaya. Proceedings of Indian National Science Academy 63: 617-624.
Kaikini, N.S., 1961. Eucalyptus in Mysore state. Proceedings of the tenth All India Silvicultural Conference, Dehra Dun, Indian Council of Forestry Research and Education, Dehra Dun, pp: 546553.

Lodhiyal L. S., Singh R. P. and Singh S. P. 1995. Structure and function of an age series of poplar plantations in Central Himalaya. I. Dr y matter dynamics. Annals of Botany 76: 191-199.

Malaya K; Mishra and Surendra K. Nisanka; 1997.Litterfall, decomposition and nutrient release in Casurainaequisetifoila plantations on the sandy coast of Orissa, India. International Society for Tropical Ecology 38 (1): 109-119.

Meentemeyer V., Box E. O. and Thompson N. R; 1982. World patterns and amounts of terrestrial plant litter production. Bio Science 32: $125-128$

Midgley, S.J., J.W. Turnbull and K. Pinyopusarerk, 2002. Industrial Acacias in Asia: Small brother or big competitor? In: Wei, R.P. and Xu, D. (Eds.) Proc. International Symposium on Eucalyptus Plantations, September 1-6, 2002, Guangdong, China, pp: 1936.

Newbould P.J. 1967. Methods for Estimation of the primary production of Forests. IBH Handbook No. 2, Blackwell Scientific Publications Oxford.

Panda T; and Mohtany R. B. 1998. Litter production by Casuarina equisetifolia L. in coastal sandy belt of Orissa. Tropical Ecology 39: 149-150.

Pande P. K; and Sharma S. C. 1986. Seasonality and pattern in leaf fall and litter accretion on the forest floor in plantations of demonstration area, Forest Research Institute and College, Dehradun (India). Indian Forester 112: 328-341.

Parihar A.K.S; and Rana B.S. 1999. 
Management practices in Agroforestry. Pp. 40-44. In: Technical Report on "Biennial Workshop on All India Coordinated Research Project on Agroforestry. (I.C.A.R.)March 6th -7th, N.D. University of Agriculture \& Technology, Kumarganj (Faizabad).

Piper C.S. 1950. Soil and plant Analysis. Interscience Publications, Inc., New York.

Rajendran K; and Devaraj P 2004. Biomass and nutrient distribution and their return of Casuarina equisetifolia inoculated with biofertilizers in farm land. Biomass and Bioenergy, 26: 235-249.

Rajvanshi R; and Gupta S. R. 1985. Biomass, productivity and litter fall in a tropical Dalbergia sissoo Roxb. forest. Journal of Tree Science, 4: 73-78.

Rana B.S., Saxena A.K; and Rao O.P. 1998. Biomass and productivity in manmade plantation of four species on sodic land. Pp. 13-17. In: Technical Report on Annual Group Meeting cum Symposium in All India Coordinated Research Project on Agroforestry (ICAR). February 6th - 7th. Kerala Agricultural University, Trichu.

Rana, B.S; Saxena A.K., Rao O.P; and Singh B.P 2007.Nutrient return to the soil through litterfall under certain tree plantations on sodic wastelands in northern India. Journal of tropical forest science, 19 (13): 141-149.

Reddell P. 1990. Increasing productivity in plantations of Casuarina by inoculation with Frankia, Pp 133-140 in el-Lakany MH, Turnbull JW and Brewbaker JL (eds). Advances in Casuarina Research. Desert Development Centre, Cairo.

Ribeiro C; Madeira M; and Arau'Jo MC. 2002. Decomposition and nutrient release from leaf litter of Eucalyptus globules grown under different water and nutrient regimes. Forest Ecology and Management 171: 31-41.

Saravanan S; Buvaneswaran C; Manivachagam P; Rajagopal K 2012. Nutrient cycling in Casuraina (Casuraina equisetifoila) base agroforestry system. India journal of forestry, 35(2): $187-191$.

Sarjubala D; and Yadava PS. 2007. Wood and leaf litter decomposition of Dipterocarpus tuberculatusRoxb. in a tropical deciduous forest of Manipur, north-east India. Current Science 93: 243-246.

Tateno R; Tokuchi N; Yamanaka N; Du S; Otsuki; Shimamura T; Xue Z; Wang S; and Hou Q. 2007. Comparison of litterfall production and leaf litter decomposition between an exotic black locust plantation and an indigenous oak forest near Yan'an on the Loess Plateau, China. Forest Ecology and Management 241: $84-90$.

Wedderburn ME; and Carter J. 1999. Litter decomposition by four tree types for use in silvipastoral systems. Soil Biology and Biochemistry 31: 455-461.

Zobel, B.J., 1993. Clonal forestry in the Eucalyptus, In Clonal Forestry: Conservation and Application (eds Ahuja M.R. and Libby W.J.), SpringerVerlag, Budapest, 2: 139-148.

\section{How to cite this article:}

Tarun Kumar, Bimlendra Kumari, Sandeep Arya and Prashant Kaushik. 2019. Tree Growth, Litter Fall and Leaf Litter Decomposition of Eucalyptus tereticornis Base Agri-silviculture System. Int.J.Curr.Microbiol.App.Sci. 8(04): 3014-3023.

doi: https://doi.org/10.20546/ijcmas.2019.804.347 